\title{
Hydrodynamic analysis of different impellers used in the stir casting process
}

\section{Analisis hidrodinámico de diferentes impulsores utilizados en el proceso de stir casting}

PÉREZ-PÉREZ, Arnulfo†*, MARTÍNEZ-VÁZQUEZ, J. Merced, RODRÍGUEZ-ORTIZ, Gabriel and GARCÍA-DUARTE, Oscar Enrique

Universidad Politécnica de Juventino Rosas, Metallurgical Engineering. Hidalgo 102, Community of Valencia, Santa Cruz de Juventino Rosas, Gto. 38253.

ID $1^{\text {st }}$ Author: Arnulfo, Pérez-Pérez / ORC ID: 0000-0001-6354-8899, CVU CONACYT ID: 176434

ID $1^{\text {st }}$ Co-author: J. Merced, Martínez-Vázquez / ORC ID: 0000-0002-6230-3846, CVU CONACYT ID: 93450

ID $2^{\text {nd }}$ Co-author: Gabriel, Rodríguez-Ortiz / ORC ID: 0000-0002-3615-1973, CVU CONACYT ID: 48565

ID $3^{\text {rd }}$ Co-author: Oscar Enrique, García-Duarte / ORC ID: 0000-0002-4781-8438, CVU CONACYT ID: 290387

DOI: $10.35429 / E J D R C .2020 .11 .6 .24 .28$

Received July 25, 2020; Accepted December 30, 2020

\begin{abstract}
In this work, the hydrodynamic behavior of four types of impellers used in the manufacture of metal matrix composites (MMC) through the stir casting process is analyzed, in order to determine which of them is adequate to generate a uniform flow in the metal. Liquid and thereby achieve a uniform distribution of reinforcing particles. The impellers analyzed are the belt type, the vane type, the propeller type and the turbine type. As a first part, the parameters of each one of them were determined to later carry out the modeling in SolidWorks. Some properties of liquid aluminum were also determined, such as density and viscosity for a melting temperature. These characteristics were assigned in the software used. As results, the flow velocities and turbulences that occur with each impeller were obtained, being the propeller-type impeller the one that shows a more uniform distribution in terms of velocities.
\end{abstract}

Impeller, Stir Casting, metal matrix composites

\begin{abstract}
Resumen
En este trabajo se analiza el comportamiento hidrodinámico de cuatro tipos de impulsores utilizados en la fabricación de compuestos de matriz metálica (MMC) mediante el proceso de stir casting, con el objetivo de determinar cuál de ellos es adecuado para generar un flujo uniforme en el metal líquido y con ello lograr una distribución uniforme de partículas de refuerzo. Los impulsores analizados son el de tipo cinta, las paletas, el de hélice y el de turbina. Como primera parte se determinaron los parámetros de cada uno de ellos para posteriormente realizar el modelado en SolidWorks. También se determinaron algunas propiedades del aluminio líquido como son la densidad y la viscosidad para una temperatura de fusión. Estas características se asignaron en el software utilizado. Como resultados, se obtuvieron los regímenes de velocidades de flujo y las turbulencias que se presentan con cada impulsor, siendo el impulsor tipo hélice el que muestra una distribución más uniforme en cuanto a velocidades.
\end{abstract}

Impulsor, Stir Casting, Compuestos de matriz metalica

Citation: PÉREZ-PÉREZ, Arnulfo, MARTÍNEZ-VÁZQUEZ, J. Merced, RODRÍGUEZ-ORTIZ, Gabriel and GARCÍADUARTE, Oscar Enrique. Hydrodynamic analysis of different impellers used in the stir casting process. Journal - Democratic Republic of Congo. 2020. 6-11:24-28.

\footnotetext{
$\dagger$ Researcher contributing as first author.
} 


\section{Introduction}

The stir casting process is used to obtain metallic matrix compounds (MMC) and was developed in 1968 when alumina particles were added to the aluminum casting. The stages in which it develops are three: the fusion of the metal, the addition of particles and stirring.

In the agitation system used, several components are necessary for its operation, these consist of a crucible which will contain the matrix material and a mechanical mixer that consists of an impeller mounted on a shaft connected to a drive unit.

Agitators are classified into axial flow and radial flow. The first allows a flow that emerges from the impeller at approximately $45^{\circ}$ presenting a recirculation, returning to the central area of the impeller, creating a flow field back and forth parallel to the axis of rotation. This type of flow occurs with a Reynolds of between 200 to 600 , and it becomes radial flow when the Reynolds number decreases. The second generates radial flow for any Reynolds and provides high tangential velocity but very low drive capacity.

The types of axial, radial and tangential flow will depend on the type of impeller, the characteristics and size of the fluid, as well as the proportions of the container (crucible). The velocity of the fluid at any point in the crucible has three components, and the predominant flow will depend on the variations in motion and the velocity of each component.

The radial flow is the first component of the fluid velocity, this velocity is radial and acts perpendicular to the axis of the impeller.

Longitudinal or axial flow is the second component, and it acts in a direction parallel to the axis.

Tangential or rotational flow is the third, this component acts in a tangential direction to the circular path described by the impeller.

The impellers are classified as propeller, turbine and blade (Figure 1), which are related to the types of flow already mentioned.

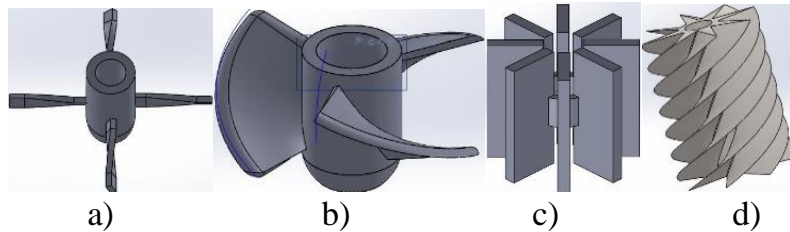

Figure 1 Impellers a) blades b) propeller, c) trubin and d) tape.

Source: Self-made

\section{Methodology}

The work was carried out by implementing numerical simulations by the finite element method by means of SolidWorks (CFD) 2018 software, where the hydrodynamic behavior of the three-dimensional flow within the stirred container (crucible) was resolved. This from the solution of the continuity equations (Eq. (1)) and Navier-Stokes (Eq. (2)) in each of the cells into which the volume under study was divided.

$\nabla \vec{V}=0$

$\rho \frac{\delta \vec{V}}{\delta t}+(\vec{V} * \nabla) \vec{V}=-\nabla p+\rho \vec{g}+\mu \nabla^{2} \vec{V}$

The materials chosen for study were the aluminum alloy A60061 reinforced with Al_2 O_3 (alumina) particles. The mean particle size was $15.3 \mu \mathrm{m}$.

The parameters considered in the oven are those shown in table 1.

\begin{tabular}{|c|c|c|}
\hline Element & Parameter & Value \\
\hline \multirow[t]{3}{*}{ Aluminum } & melting temperatura & $620^{\circ} \mathrm{C}$ \\
\hline & casting temperature & $750^{\circ} \mathrm{C}$ \\
\hline & density & $2700 \mathrm{~kg} / \mathrm{m} 3$ \\
\hline \multirow[t]{6}{*}{ Melting pot } & material & grafito \\
\hline & capacity & $3.68 \mathrm{~m} 3$ \\
\hline & thickness & $25.4 \mathrm{~mm}$ \\
\hline & Diam. upper D & $0.78 \mathrm{~m}$ \\
\hline & Diam. Lower d & $0.53 \mathrm{~m}$ \\
\hline & Height $\mathrm{H}$ & $0.90 \mathrm{~m}$ \\
\hline \multirow[t]{2}{*}{ Agitator } & Impeller type & $\begin{array}{l}\text { Paleta, hélice, } \\
\text { turbina o cinta }\end{array}$ \\
\hline & Flow type & $\begin{array}{ll}\text { Num. } & \text { de } \\
\text { Reynolds } & \end{array}$ \\
\hline
\end{tabular}

Table 1 Characteristics of the oven Source: Self-made

The volume of the crucible was determined with equation 3 .

$V r=\pi * H *\left(D^{2}+d^{2}+D * d\right)$ 
Taking into account the data in table 1 , the volume of the crucible obtained is $\mathrm{Vr}=3.69$ $m^{3}$.

Since only $75 \%$ of the crucible capacity must be used at most to avoid breakdowns, the maximum mass that can be entered is $m_{\max }=$ $2,500 \mathrm{~kg}$.

For the sizing of the different impellers analyzed in this study, the relationships in Table 2 were used.

Where D_a is the diameter of the impeller, D_t is the diameter of the crucible, $\mathrm{E}$ is the distance from the bottom of the crucible to the impeller, $\mathrm{H}$ is the height of the metal, $\mathrm{W}$ is the width of the impeller, $\mathrm{J}$ is the width of the plate, $L$ is the length of the impeller blade and $f$ is the space between the plate and the crucible (Figure 2).

\begin{tabular}{|l|l|l|l|}
\multicolumn{5}{c}{ Impeller type } \\
\multicolumn{1}{c|}{ Pallas } & Propeller & \multicolumn{1}{c|}{ Turbine } & \multicolumn{1}{c|}{ Headband } \\
\hline$\frac{H}{D t}=1$ & $\frac{H}{D t}=1$ & $\frac{H}{D t}=1$ & $\frac{H}{D t}=1$ \\
\hline$\frac{D a}{D t}=0.33$ & $\frac{D a}{D t}=0.33$ & $\frac{D a}{D t}=0.33$ & $\frac{D a}{D t}=0.33$ \\
\hline$\frac{E}{D t}=\frac{0.17}{0.34}$ & $\frac{E}{D t}=0.33$ & $\frac{E}{D t}=0.33$ & $\frac{E}{D t}=0.33$ \\
\hline$\frac{W}{f}=0.177$ & & $\frac{W}{D a}=0.2$ & \\
\hline$<=45^{\circ}$ & $<=25^{\circ}$ & $\frac{g}{D a}=0.25$ & $<=25^{\circ}$ \\
\hline$\frac{J}{D t}=0.1$ & $\frac{J}{D t}=0.1$ & $\frac{J}{D t}=0.1$ & $\frac{J}{D t}=0.1$ \\
\hline & $\frac{f}{J}=0.02$ & $\frac{f}{D t}=0.02$ & $\frac{f}{J}=0.02$ \\
\hline
\end{tabular}

Table 2 Relationships between parameters for the different drivers

Source: Self-made

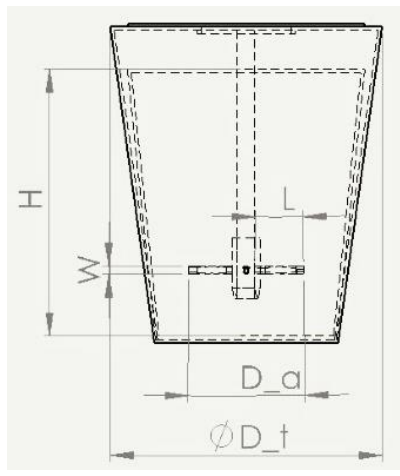

Figure 2 Parameters of a stirring system Source: Adapted from Castillo

The density of aluminum at melting temperature (933 K to $1190 \mathrm{~K}$ ) was determined with equation (5) proposed by Preston-Tomas

$\rho=c_{1}-c_{2}\left(T-T_{\text {ref }}\right)$

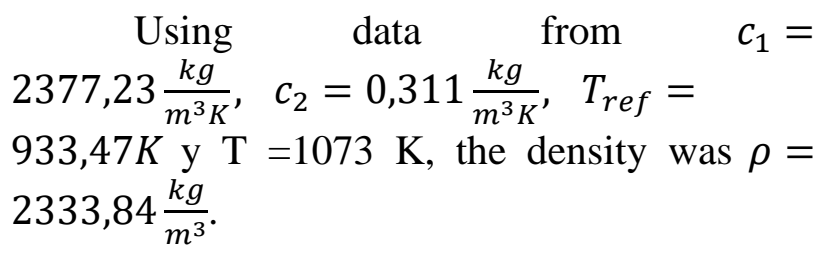

Another property to take into account during the simulation was the viscosity, which was determined by equation (6).

$\log _{10}=\frac{\mu}{\mu_{o}}=-a_{1}+\frac{a_{2}}{T}$

Where $\quad \mu_{o}=1 \mathrm{mPas}, a_{1}=$ $0,7324, a_{2}=803.49 k$ and the resulting value was $\mu=0.001035 \frac{\mathrm{kg}}{\mathrm{ms}}$

In order to carry out the simulation of the study and that the parameters have a limit border, three extra pieces were developed: Two cylinders and a solid that simulated the liquid inside the crucible. One of the cylinders surrounds the impeller in all its geometry and was used to indicate the rotating section. The second cylinder is a larger one that is enveloping and containing the crucible and the entire system to be simulated. Its purpose was to contain the area where environmental forces such as pressure and gravity act.

\section{Results}

After having made the models, having entered the parameters for the simulation, and running the simulation, the resulting velocity values are shown in Figure 4 for the different impeller models analyzed.

As observed in each of the analyzes, a vortex is generated above the impeller and a vortex below it. This is most marked in the situation where the turbine impeller and the belt impeller are used.

In contrast, the impeller that generates more homogeneous flow lines is the propeller impeller. 

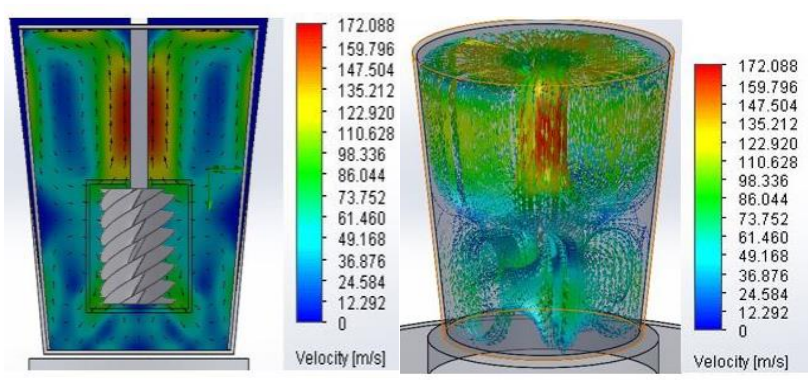

a)
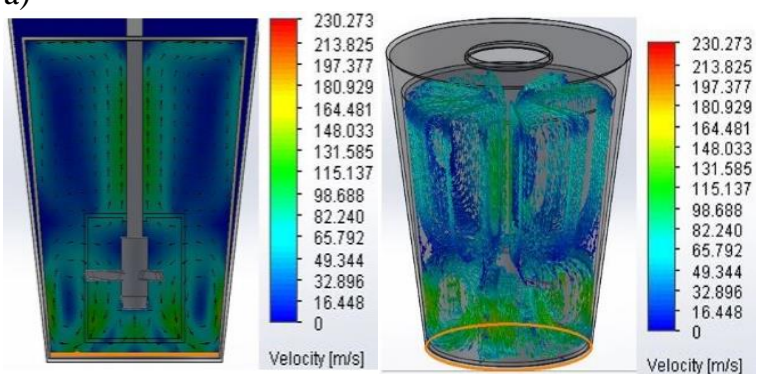

b)
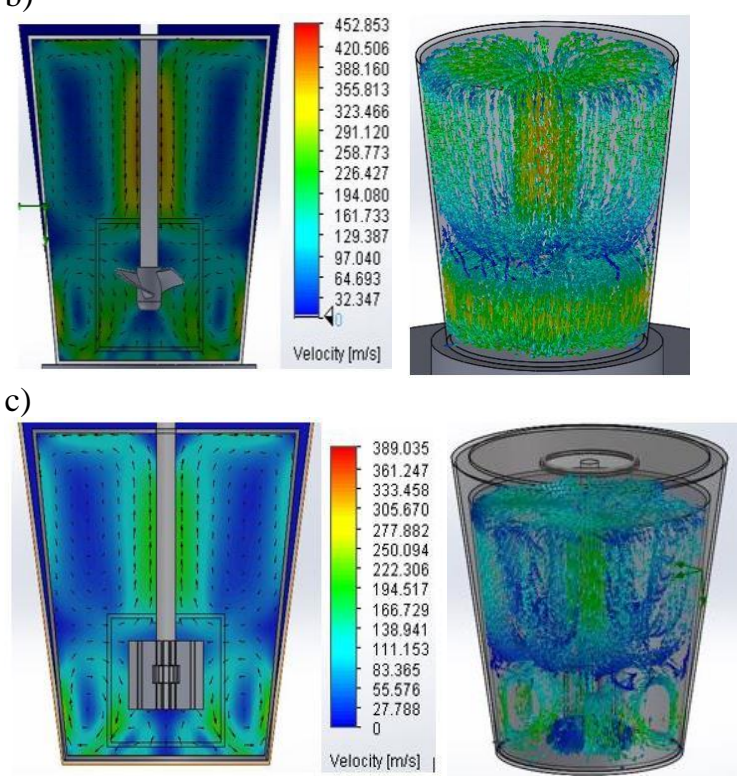

d)

Figure 3 Speeds (m / s) obtained during the dynamic simulation with the different impeller models. a) Belt, b) Vane, c) Propeller and d) Turbine

Source: Self-made

Although the turbulence energy can be predicted in Figure 3, the values of this variable can be observed more clearly in Figure 4. The impellers that generate the highest concentrations of turbulence energy are the blades and propellers.

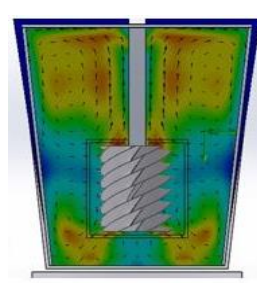

a)

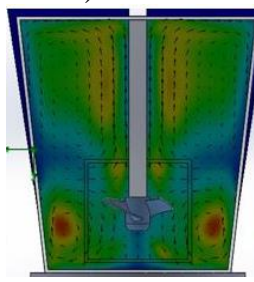

c)

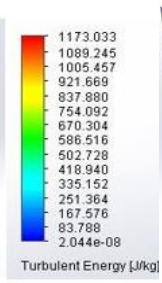

b)
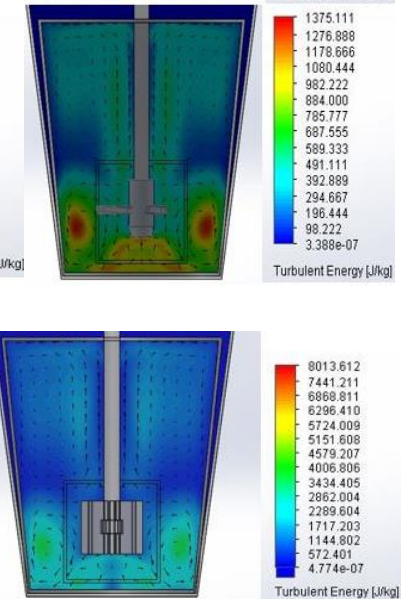

d)

Figure 4 Turbulence energy ( $\mathrm{J} / \mathrm{kg}$ ) obtained from the simulation when applying the various impellers. a) Belt, b) Blades, c) Propeller, d) Turbine Source: Self-made

In the case of the turbine impeller, even when the turbulence energy values are shown constant, their values are high compared to those resulting in the other analyzes.

\section{Conclusion}

The various impeller models and the various parameters that define them, as well as the physical characteristics of the molten metals and the particles added to generate metal matrix composites, complicate the process of selecting a good stirring system for the Stir process. Casting.

However, the various finite element computer programs have come to be a great support for obtaining approximations of hydrodynamic behavior.

For this work, the SolidWorks simulation part allowed to solve the continuity equations of a stirring system with different impellers, to determine the speed and turbulence regimes inside the crucible.

The results of the simulation indicated that the propeller type impeller is the one that generates flow lines with more homogeneous speeds and that, therefore, would generate a better distribution of the particles. 


\section{References}

da Costa, C. E., López, F. V., \& Castelló, J. M. T. (2000). Materiales compuestos de matriz metálica. I parte. Tipos, propiedades, aplicaciones. Revista de metalurgia, 36(3), 179192.

Hernández-Montecillo, V. M. (2019). Análisis Numérico De La Hidrodinámica En Tanques Agitados A Través De Implementar Una Turbina Rusthon. JÓVENES EN LA CIENCIA, 6.

Valencia, M., Morales, A., \& Martínez, V. (2007). Compoforjado de materiales compuestos base al-si, reforzados con $\beta$-sic. Scientia et technica, 1(36).

Morales, A., Sanchez, S., Valencia, M. F., Zuluaga, C., Riaño, L. J. C., \& Martínez, V. (2007). Diseño y puesta a punto de una nueva tecnologia de fundicion semisólida para composites metalicos en colombia. Scientia et technica, 1(36).

Oliveros, C. E., Alvarez, F., \& Montoya, E. C. (1997). Metodología para el escalamiento de agitadores mecánicos utilizados en procesos con fluidos no-newtonianos. Revista Facultad Nacional de Agronomía Medellín, 50(1), 31-54. Verdugo Leal, R. H. (2013). Diseño y cálculo de un agitador de fluidos.

Caneo Cartagena, E. A. (2017). Creep de compuestos de A16061/Nano A1203 fabricados por proceso de stir casting.

Peña Hechavarría, I. (2017). Construcción de un crisol de grafito para la fusión de ferroaleaciones a escala de laboratorio (Doctoral dissertation, Departamento de Mecánica).

Forn, A., Rupérez, E., Martín, E., \& Picas, J. A. (2007, March). DEFORMACIÓN PLÁSTICA DEL MATERIAL COMPUESTO A6061/A12O3p. In Anales de la Mecánica de Fractura (Vol. 1).

Taco Quispe, M. T. (2018). Estudio sobre el comportamiento mecánico de un compuesto de matriz metálica $\mathrm{Al}-\mathrm{SiO} 2$ utilizando como materia prima latas de Aluminio y Cascarilla de Arroz.
Bolívar Martínez, R. D. (2013). Análisis, diseño y modelamiento por elementos finitos del eje para un agitador mecánico de la empresa Flow Control and Handling SA (Bachelor's thesis, Universidad Autónoma de Occidente).

Quispe Zuñiga, M. K. (2019). Determinación del tamaño de partícula óptimo de la sílice amorfa que actúa como reforzante en un composito de matriz metalica.

Martínez, H. V. (2007). Metalurgia semisólida de aleaciones y composites metálicos procesados por agitación mecánica. Revista latinoamericana de metalurgia y materiales, 27(1), 13-27.

Vera, S., Cortés, M., Rao, J., Fazio, P., \& Bustamante, W. (2015). Evaluación de modelos de turbulencia para predecir los flujos de masa de aire interzonas a través de una abertura de escalera para la convección natural y mixta en los edificios. Revista ingeniería de construcción, 30(2), 85-97.

Gustavo, R., (2019). Modelos de turbulencia introductorio (DOI: https://www.researchgate.net/deref/http $\% 3 \mathrm{~A} \% 2$ F\%2Fdx.doi.org\%2F10.13140\%2FRG.2.2.2106 0.17289 )

Cercado Bueno, M. N., \& Yuquilema Guamán, C. O. (2018). Diseño y construcción de un sistema de inyección y agitación para fabricación de aleaciones no ferrosas reforzadas con partículas cerámicas nanométricas (Bachelor's thesis, Espol).

Ramírez-Muñoz, J., García-Cortés, D., ColínLuna, J. A., \& Tapia-Medina, C. R. (2016). Efecto de la Evolución del Vórtice sobre los Parámetros Hidrodinámicos de un Sistema de Dispersión Mecánica de Pigmentos. Información tecnológica, 27(4), 145154. 